\title{
Heroes and Villains in 2 Maccabees 8:1-36 - A Rhetorical Analysis
}

\author{
EUGENE COETZER (NORTH-WEST UNIVERSITY)
}

\begin{abstract}
In recent years, scholarly contributions to the study of 2 Maccabees have shifted towards a focus on larger themes and rhetorical elements. This, in turn, allowed for a deeper understanding of the narrative aim and the persuasive nature of the text. This article builds on traditional rhetorical analysis and adds to the discussion by investigating a neglected aspect namely the communicative strategy. It further explores an otherwise unnoted concept: a contract of trust between the implicit reader and a group or individual within the text. The vindication and legitimisation of the group of heroes within the text is shown to be a fundamental element in a strategy which presents the heroes as fully authoritative and their actions as unquestionable. Such a communicative strategy proves to be ideal for moving the reader to adopt the main proposition: the fate of the Jews is intimately connected to the scale of God's wrath and mercy.
\end{abstract}

KEYWORDS: Rhetoric; Communicative Strategy; Narrative Aim; 2 Maccabees; Jewish Identity, Judaism.

\section{A INTRODUCTION}

An aspect that is inseparable to a clear understanding of 2 Maccabees is the way in which the author goes about affecting the audience in order to achieve a change in their point of view. Robert Doran remarks that this work is "not a history of the Maccabees' revolt against their Seleucid overlords in the modern sense of the word "history." "He proceeds by stating that 2 Maccabees is a highly rhetorical narrative that sets out not to give a "blow-by-blow description of events but to move its audience to commit to faithfully following the ancestral traditions of Judaism.", Despite the emphasis on Judaism, ${ }^{3}$ the text demonstrates a clear understanding and employment of Greek rhetorical style. ${ }^{4}$

* Article submitted: 31/07/2016; article accepted: 29/09/2016. To cite: Eugene Coetzer, "Heroes and Villains in 2 Maccabees 8:1-36 - A Rhetorical Analysis," OTE 29 (3) 2016: 419-433. Doi: http://

dx.doi.org/10.17159/2312-3621/2016/v29n3a4

1 Robert Doran, 2 Maccabees: A Critical Commentary (Minneapolis: Fortress Press, 2012), 1

2 Doran, 2 Maccabees, 1.

3 The author of 2 Maccabees is the first we know to speak of Judaism.

4 Doran, 2 Maccabees, 1. 
Such a highly rhetorical inclination becomes apparent in 2 Macc 8, where the normal aspects of historiography are reinforced by colourful details about specific characters and the nature of events. It is imperative not to be distracted by the apparent dominance of the subject matter of 2 Maccabees. To clarify: if the subject of 2 Maccabees is as Daniel Schwartz clearly describes it,

the history of the city of Jerusalem from the beginning of institutionalised Hellenisation under the high priest Jason around 175 B.C.E. and until Judas Maccabaeus' victory over the Seleucid general Nicanor in the spring of 161 B.C.E., 5

then the function of a rhetorical investigation would be to ask "why" and "how" this history and theme is communicated. Furthermore, these two questions, the "why" and the "how" respectively need individual attention. Firstly, why does the author provide a recount of this specific portion of Jewish history? The answer to the "why" will lead to the purpose of the text. The second question is how the author is persuading his audience to conform to this purpose. This question can be answered through studying types of explicit or implicit arguments (authorative, emotional or logical etc.) evident within the text.

Regarding the first of the two, the "why," various key contributions to the study of 2 Maccabees exist:

- Elias Bickerman ${ }^{6}$ aims his book as a preliminary study for a commentary on 1 and 2 Maccabees. His book developed out of a philological interpretation and has a "purely historical" aim in order to understand the sequence of events and make them comprehensible. ${ }^{7}$ Amongst his foci are the dating of the prefixed letters and the book, the differences of the various traditions, and the original aggressors of the persecutions.

- Robert Doran ${ }^{8}$ highlights the author's love for metaphors and wordplay. He focuses on worldview and the confrontation between Judaism and Hellenism. His research shows interest in some rhetorical aspects of the text and accordingly investigates the goals of the text. Pierre Jordaan highlights the benefit of Doran's dealing with larger narrative units and acknowledgment of the prominence of, for example, the Jerusalem temple. ${ }^{9}$

5 Daniel R. Schwartz, 2 Maccabees (Berlin: Walter de Gruyter, 2008), 3.

6 Elias J. Bickerman, The God of the Maccabees: Studies in the Meaning and Origin of the Maccabean Revolt (Leiden: Brill, 1979).

7 Bickerman, God of the Maccabees, 1.

8 Doran, 2 Maccabees.

9 Pierre Jordaan, "The Temple in 2 Maccabees - Dynamics and Episodes," JSem 24 (2015): 354. 
- Jonathan Goldstein ${ }^{10}$ follows his doktorvater, Bickerman, except in the dating of 2 Maccabees. He examines the critical issues raised by 2 Maccabees. He discusses its language and style, its Hellenistic and Jewish inclination, its comparison and relationship to 1 Maccabees, its use of sacred writings (Torah and Prophets), its historical context, and the role of the miraculous.

- Schwartz ${ }^{11}$ highlights 2 Maccabees as a second century BCE Jewish writing. He accentuates 2 Maccabees as a narration and interpretation of the events that took place in Jerusalem prior to and during the Maccabean revolt (167-160 BCE). He provides an important solution to the intricate discussion on the linkage between the letters and the narrative in arguing that the authors of the first letter took notice of the book and that the second letter is closely linked to the narrative concerning the fire in the Temple. ${ }^{12}$

- Jan Willem Van Henten ${ }^{13}$ discusses the religious, political as well as the philosophical aspects of noble death in 2 and 4 Maccabees. In discussing the narrative, he distinguishes six elements which are a key facet in understanding the narrative pattern of 2 Maccabees. ${ }^{14} \mathrm{He}$ argues that the theme of martyrdom is a very important part of the self-image of the Jews as presented by the authors of both works. Eleazar, the anonymous mother with her seven sons and Razis should, therefore, be considered heroes of the Jewish people.

Although Doran's work is closest to a purely rhetoric focus, the "how' is still left somewhat unattended. This article deals with the "how" in 2 Macc 8, in other words, with the communicative strategy applied in order to sell certain ideas to the implicit reader.

Furthermore, a new element will be added to the usual rhetorical concept of a contract of trust. Whereas the focus would normally be on a contract of trust established between the author and the implicit reader, this analysis would focus on a contract, not between the author and the reader, but between a group of characters within the narrative and the reader. In this manner, the text is shown to communicate a specific ideology through the actions and words of a blameless and trusted group of individuals within the narrative: the heroes of 2 Maccabees.

10 Jonathan A. Goldstein, II Maccabees: A New Translation with Introduction and Commentary (Garden City, N.Y.: Doubleday, 1983).

11 Schwartz, 2 Maccabees.

12 Schwartz, 2 Maccabees, 525-527.

13 Jan-Willem van Henten, The Maccabean Martyrs as Saviours of the Jewish People: A Study of 2 and 4 Maccabees (Leiden: Brill, 1997).

14 Van Henten, Maccabean Martyrs, 295. 


\section{B METHODOLOGY ${ }^{15}$}

In order to isolate and analyse the communicative strategy of the pericope, the variety of facets pertaining to a contract of trust need to be identified within the text. The following issues will be addressed:

- Determining the unacceptable and desired epistemic practice. In this study this would involve perceptual nuances rather than practice. To simplify: the text does not address specific actions, but rather challenges specific ideas that might be manifested in the mind of the implicit reader. A communicative strategy would thus be applied in order to move the implicit reader towards such a desired epistemic practice/perception. After identification and clarification, this desired perception will be formalised in the form of a main proposition.

- Ascertaining which parties are involved. As mentioned above, this article demonstrates the presentation of specific characters within the text as ideal party for a contract of trust. The characters which make up such a party will be identified.

- Analysing the manner in which the text presents these characters. All elements adding to the vindication and legitimisation of this party will be investigated. Consequently, these characters will be highlighted as role-players in the communicative strategy, since they become the vehicles for propagating the proposition.

As a basis for this pragmatic analysis, a structural analysis will be executed. This will clarify the eventual proposition, minimize ambiguity, and stabilise the text. As part of the structural analysis, the text of 2 Macc 8:1-36 will be:

- delimited as an analytical unit,

- analysed syntactically,

- analysed semantically,

- and referenced intra- and inter-textually

This methodology will now be applied to the text.

15 This methodology is a transformed version of Eugene Coetzer and Pierre Jordaan's article on the communicative strategy in 2 Macc 3. See Eugene Coetzer and Pierre J. Jordaan, "Investigating the Communicative Strategy in 2 Maccabees 3: Six Scenes which Influence the Reader throughout the Narrative," HTS Teologiese Studies/Theological Studies 72/3 (2016): 6 pages, doi: http://dx.doi.org/10.4102 /hts.v72i3.3047. Here, the methodology has been tailored to more clearly connect the different systematic elements to the establishment of the communicative strategy. 


\section{STRUCTURAL ANALYSIS}

\section{Delimitation}

The thematic change between the previous pericope, 6:9b-7:42, and 2 Macc 8 is a clear indication that a new pericope starts at $8: 1$. This verse $(8: 1)$ is connected to the preceding by a $\mu \dot{\varepsilon} \nu$ o $v$ v... $\delta \dot{\varepsilon}$ construction, which Doran shows to be often used by the author as he passes to another subject $(3: 22-23 ; 9: 28-10: 1$; $10: 22-23 ; 10: 28 ; 11: 18,19) .{ }^{16}$ The previous pericope dealt specifically with the instances of martyrdom. The current section starts off with Judas' recruitment of those who are steadfast in Judaism. This picks up the sub-narrative of the hope that lies in the group of Judas Maccabeus, which started in 5:27. The

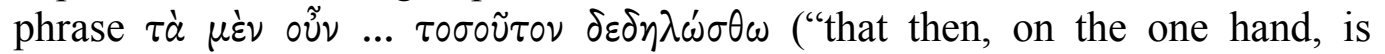
enough set forth") is self-explanatory of the ending of the previous pericope at $7: 42$.

The ending of this pericope is made clear by the shift in theme between 8:36 and 9:1 onward. The author begins with the gathering of Judas' force and Nikanor's invasion (8:1-15) and returns to the description of Nikanor's flight and recognition of the Champion of the Jews in 8:34-36. Thereafter, a new

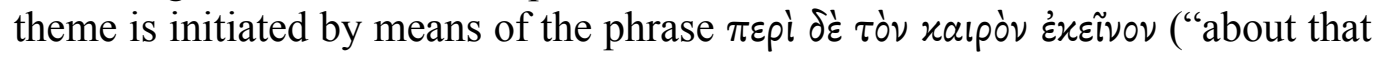
time") in 9:1. A similar phrase starts a new section in ch. 5 ( $\pi \varepsilon p i$ dè $\tau \dot{c} v$ xalpòv

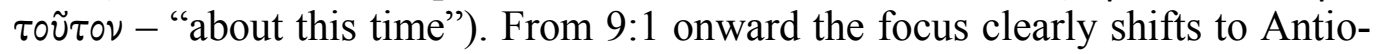
chus IV Epiphanes. Consequently, the current pericope may be delimited as $8: 1-36$.

\section{Syntactical and Semantic Analysis}

In the prologue of 2 Maccabees, the author states one of his aims as describing the resistance of those who fought eagerly on behalf of Judaism. This aim is interwoven into the text through the threat of Hellenism by Jason and Antiochus. It is Hellenism versus Judaism. Now, in 8:1-36 the aim is further visible through the expanding force of Judas that is identified by their zeal for Judaism.

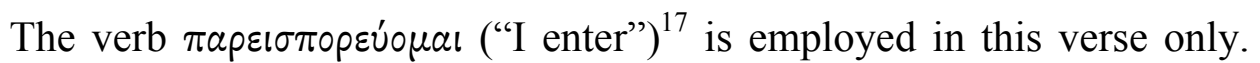
This led Schwartz to provide a translation that takes the prefixed prepositions into account, "they had been going in and out and around." "The fact that this form of the verb is only used here merits such a specific translation.

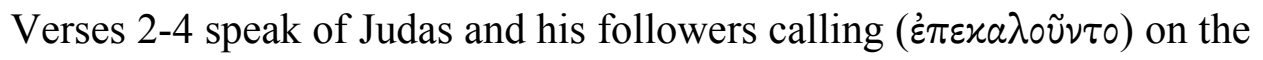
Lord. The reader is reminded of the prayer of the seventh brother in 7:37

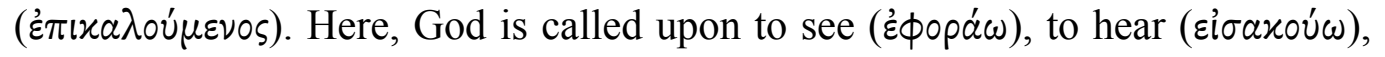

16 Doran, 2 Maccabees, 170.

17 LSJ, 1334.

18 Schwartz, 2 Maccabees, 320. 
and to remember $(\mu \mu \nu \eta \dot{\sigma} \sigma \omega)$. God must see all the maltreated people, hear the cry of the blood, and remember the destruction of the infants. In Exod 2:24-25 God also acts in this threefold manner (see, hear and remember). The prayer calls for God's vengeance. This, along with the mention of the blasphemies

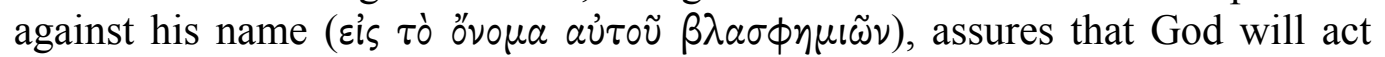
(just as the he promised doom to blasphemers in Ezek 35:12-14). At the same time, the prayer calls the reader to action. The reader is reminded of the horrid maltreatment of the Jews and is now anticipating retribution. The pairing of the

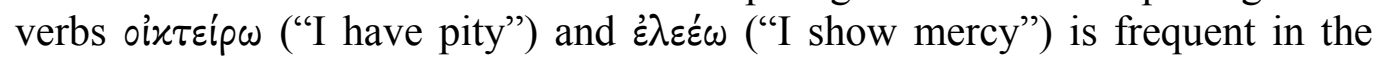
LXX (Exod 33:19; 3 Kgdms 8:50; 4 Kgdms 13:23; Ps 76:9-10). The call to

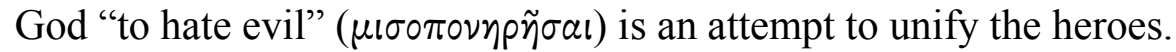

In 8:5, Judas got his troops together ( $\left.\varepsilon^{\prime} \nu \sigma \nu \sigma \tau \varepsilon \dot{\varepsilon} \mu \tau \iota\right)$. The term $\sigma \dot{\sigma} \sigma \tau \eta \mu \alpha$ ("that which is put together") is frequently employed by Polybius in terms of the organisation of military forces $(1.81 .11 ; 3.53 .6 ; 8.26 .8)$. The action of gathering followers is connected with the succeeding events through the adverb of time (" $\delta \eta$ - "forthwith"). However, 8:5 mentions that Judas alone could not be

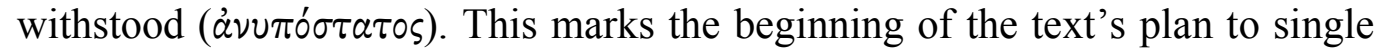
out Judas and thus making him an effective heroic character.

As mentioned earlier, the fact that Judas' force cannot be withstood by the gentiles is due to the fact that the wrath of the Lord had turned to mercy (8:5). This is an explication of the author's previous theological reflections as well as an echo of the prayer in 2 Macc 7:38. It is a turning point of the entire narrative in terms of the success of the Jews and highlights the significance of the events which closely precede this chapter namely the persecution and blood flow of the martyrs.

In 8:6-7, mention is made of the surprise tactics of Judas. The sense of swiftness of this whole process is heightened through two asyndetic participle

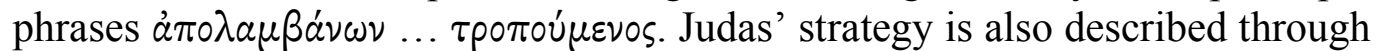

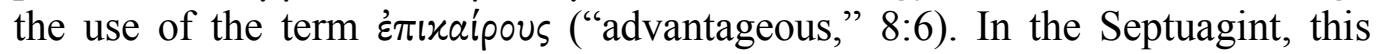
adjective recurs only in 2 Maccabees $(8: 31 ; 10: 15 ; 14: 22)$. Elsewhere, the term is used with the sense of "strategic" (Xenophon, Hier. 10.5). Bezalel BarKochva makes a convincing case for the view that here, in 8:6, the term refers to Judas choosing his point of attack, rather than strategic positions. ${ }^{19}$ Nevertheless, no other details are provided regarding either strategic positions or point of attack. In this manner, the author shows the reader that such details are not the aim of this narrative.

When Onias III realised the threat of Simon's attacks in 2 Macc 4:4, the term ouvopáw ("I detect") is used. Here, in 8:8 again, the term is used for Philip the Phrygian's realisation of Judas' threat. This detection on behalf of Philip is

19 Bezalel Bar-Kochva, Judas Maccabaeus: The Jewish Struggle against the Seleucids (Cambridge: Cambridge University Press, 1989), 138-141. 
due to the progression of success made clear by the author through referring to

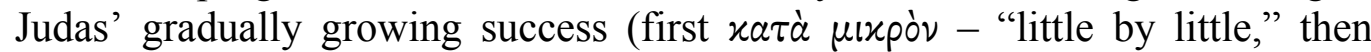

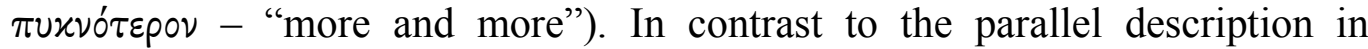
1 Macc 3:10-25, the author of 2 Maccabees focuses on the victory over Nikanor. Thus, the focus is on the victory over this Nikanor, who is a highranking noble official (one of the First Friends) and "triply offensive" (8:34:

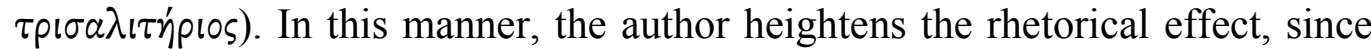
this powerful man is no match for Judas and his God.

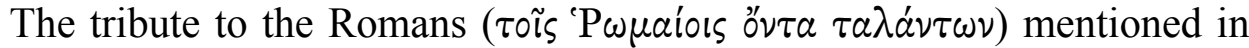
8:10 seems most likely to be part of the moneys payable to the Romans according to the Treaty of Apamaea in 188 BCE after the Seleucid defeat at Magnesia. This treaty determined that the Seleucids should pay twelve thousand talents to the Romans over twelve years (one thousand per year, Polybius 21.42.19). Accordingly, these two thousand talents (8:10) would form part of that twelve thousand talents and would be worth two years of payments. The problem, however, is that these payments should have already been finalised in 176 BCE. Otto Mørkholm argues that Antiochus IV Epiphanes had paid off the indemnity in 173 BCE. $^{20}$ Mørkholm's argument is, however, based on an ambiguous quote from Livy (42.6.7) which speaks of Antiochus IV Epiphanes' ambassador apologising to the senate for paying an overdue instalment and that he has brought the entire instalment. It is not certain whether the ambassador brought the entire instalment that was left from the twelve thousand or if he meant the entire instalment for that year. This uncertainty led Schwartz ${ }^{21}$ and, following him, Doran ${ }^{22}$ to leave this matter unresolved. A fact that is certain, however, is that the author has utilised this account as a rhetorical tool. The reader is provoked through the fact that Jews would be sold for the mere purpose of paying tribute to the Romans. The fact that ninety slaves are sold for a talent (8:11: which calculates into 67 drachmas per slave, ${ }^{23}$ means that the Jews were sold for half the normal rate. Reinhold Scholl provides prices ranging from 112 to 300 drachmas per slave. ${ }^{24}$ This drastic drop in price would have been due to the vast number of slaves that Nikanor intended to sell. This further heightens the rhetorical effect, since that was even less than the price of an animal. $^{25}$

Another rhetorical aspect is the fact that the author singles out a hero and a villain and places them against each other as antagonists. This happens

20 Otto Mørkholm, Antiochus IV of Syria CMD 8 (Copenhagen: Gyldendal, 1966), 65 .

21 Schwartz, 2 Maccabees, 544-45.

22 Doran, 2 Maccabees, 173.

23 Schwartz, 2 Maccabees, 333.

24 Reinhold Scholl, Corpus der ptolemäischen Sklaventexte (Stuttgart: Steiner, 1990), 213.

25 Schwartz, 2 Maccabees, 333. 
through highlighting the fact that Nikanor alone (and not the usual slave traders) drives the process of enslaving the Jews and then immediately shifting the focus to Judas in 8:12. It is the brave and pious Judas against the haughty and foolish Nikanor.

In 8:13-14 the author allows for the purification of Judas' force. In Deut 20:5-9 preparations are made for certain persons to leave the battle ground and go back home. Amongst these who may legitimately leave battle are those who built new houses, those who planted new vineyards, those who have recently become engaged to a woman, and those who are weak and afraid. In the first book of Maccabees these prescriptions are explicated in the text. Here, in 2 Maccabees, there is no legitimate reason for leaving battle. They cowardly leave the Judas group, but their action is not legitimised. Their action is judged negatively through the use of the verb $\delta\llcorner a \delta ı \delta \rho a ́ \sigma x \omega$ ("I run off"). They are cowards who run away (8:13), leaving only those who are fully committed to the cause of fighting for Judaism. Those who stay behind to fight must sell everything, since no possessions may hold them back.

It is significant then that, only after the weak ones left the group, they beseech the Lord (8:14-15). It is a group that has recently been purified and they are now depicted as both strong and pious. The group calls on God to remember his covenants ${ }^{26}$ and his name that is upon the Jews (8:15). The author underpins certain important traits of the group, as is the case with other heroic figures in 2 Maccabees such as Onias III. Here, Judas' force is described as selfless (they do not ask for their own victory, but for the return of the recently enslaved) and humble (since they have respected their ancestors more than themselves).

The speech of Judas to his followers in 8:16-20 is also a speech of the author to his readers. They are reminded, firstly, of the unholy actions against Jerusalem and its Temple as well as the dissolution of the ancestral laws (8:1617). This provokes both the members of Judas' force and the readers. They are assured of the just cause of the subsequent battle and the reader's absolute loyalty to Judas and his force is secured. Secondly, both Judas' followers and the reader are reminded that the Jews have a history full of examples where the few conquered the many (8:18-20). This braces Judas' force and provides enough hope to proceed into battle. Furthermore, the reader's anticipation is ensured by means of the promise of what is about to happen: the few are going to conquer the many. This speech contains many elements present also in the pre-battle speeches found in Herodotus, Thucydides, Xenophon, and Polybius ${ }^{27}$ such as:

26 The plural "covenants" ( $\delta$ เ $\theta \theta \dot{\eta}$ xas) is rare in the LXX, appearing only in Wis 18:22; Sir 44:11, 18; 45:17.

27 Kendrick W. Pritchett, Essays in Greek History (Amsterdam: Gieben, 1994) 101105 . 
- previous battle experiences,

- the goals set (amongst which is to take vengeance on those wishing to enslave them and to defend the country),

- a comparison of forces,

- and a call for help from the gods.

The author of 2 Maccabees once again demonstrates his knowledge of Hellenistic literature through incorporating these well-known motifs and adding a unique perspective. Interestingly, as Doran notes, the emphasis in this speech falls on God's help in contrast to the Greek tendency to focus upon the battle training of the soldiers. ${ }^{28}$

Previously, Simon (4:1) and Jason (5:8) had been described as against the fatherland, while Menelaus was portrayed as a traitor to both the laws and the fatherland (5:15). Now, in 8:21, Judas and his followers prepare themselves to die for the laws and the fatherland. This, once more, is an example of the author placing the hero exactly opposite the villain. This same strategy is evident in the fact that the main hero, Judas, is pitting himself against Nikanor $(8: 23)$.

A comparison between 2 Macc 8:21-23 and 1 Macc 4:1-22 shows the unique aim of the second book of Maccabees. The author is not interested in providing a detailed description of all the tactical facets. The text hurries towards the defeat of the villain, Nikanor, by the hero, Judas. The text of 2 Maccabees describes the division of Judas' men into four groups of 1500. This type of grouping is not found in the Hebrew Scriptures. ${ }^{29}$ The account of 1 Maccabees, however, speaks of thousands, hundreds, fifties and tens and finds precedent through the regulations in Exod 18:21, 24. With this rough grouping of Judas' men in mind, Doran rightly concludes that the term $\sigma \pi \varepsilon i p a$ in 8:23 must be given the general meaning of "unit," rather than the smaller group in a fully organised army, equivalent to a Roman maniple of two hundred men. ${ }^{30}$

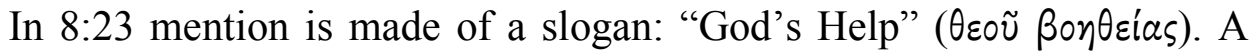

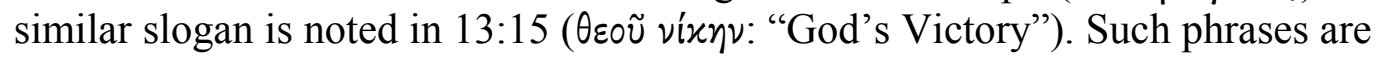
commonly found in Greco-Roman writings (Xenophon, Cyr. 3.3.58; Anab. 1.8.17; 6.5.26; Apian, Bell. civ. 2.76). What is important here is that these slogans in 2 Maccabees represent one of the main themes within second Maccabees. As mentioned above, it is important for the author to underpin the view that God controls the faith of the Jews. When he is angry, the Jews have no assurance of his protection; when he is reconciled with his children, no force can stop him. Accordingly, these slogans state that it is God's help that ensures victory and therefore the victory is his.

28 Doran, 2 Maccabees, 175.

29 Schwartz, 2 Maccabees, 339.

30 Doran, 2 Maccabees, 177. 
The reference in 8:24 to God as the ally ( $\sigma \dot{u} \mu \mu a \chi 0 \varsigma$ ) of Judas' force represents the author's aim to legitimise their actions. The fact that they are fighting beside God himself makes it hard for the reader to contest any of their actions. This, together with the emphasis of their piety, as mentioned above, guarantees the reader's loyalty to the group. The same strategy is also present in Josephus (Ant. 12.285) where he contrasts the legitimacy of the Hasmoneans (who had God as their $\sigma \dot{v} \mu \mu a \times 0 \varsigma$ ) and the rebels of his own day. ${ }^{31}$

As mentioned above, it is important for the author to depict Judas and his followers as pious. This makes it harder for the reader to criticise any of their actions. The group becomes an epithet for what is right. Another example of this strategy is seen in 8:25b-27. The author explicitly describes Judas' force taking part in the Sabbath, blessing and singing praises to the Lord (8:27), and making communal supplication and beseeching the Lord (8:29). They abandon the pursuit of the enemy troops and risk losing their advantageous position (8:25-26). This move is explained by the author of 2 Maccabees as due to the Sabbath day drawing near. Thus, for Judas and his men, obedience to the law reigns over all other endeavours. Significantly, the author of 1 Maccabees (4:15) holds that the reason for abandoning the pursuit was that Judas' force was getting too close to the coastal cities (which was not strategically ideal). The author of second Maccabees clearly has an agenda to base the actions of the book's heroes theologically.

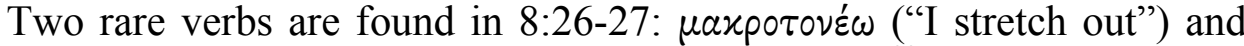
$\delta \pi \lambda \circ \lambda \circ \gamma \varepsilon \dot{\varepsilon} \omega$ ("I collect weapons"). Liddel, Scott and Jones ${ }^{32}$ list 8:26 alone for

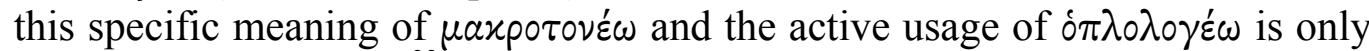
found in $8: 27$ and $8: 31 .^{33}$

In 8:30 the theme of the few conquering the many is explicated. Judas' force destroyed more than twenty thousand of Timothy and Bacchides' followers $(8: 30)$. This defeat is connected with the previous verse through the fact that

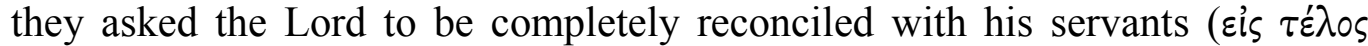

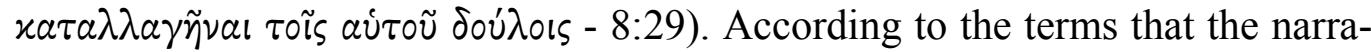
tive has already determined, they were actually asking the Lord to give them complete victory. Amongst the rare verbs already mentioned which the author uses to achieve an artistic reading of the narrative, the verb ouvepi' $\omega$ ("I clash") is employed in 8:30. This verb is only found in the LXX in 8:30. ${ }^{34}$

Adding to the list of their virtues, Judas' force shares the booty with the tortured, widows, orphans and elders. There are a few references in the Hebrew

31 Isaiah M. Gafni, "Josephus and I Maccabees," in Josephus, the Bible, and History, ed. Louis H. Feldman and Gåohei Hata (Leiden: Brill, 1989), 126-127.

32 LSJ, 1075.

33 LSJ, 1240.

34 LSJ, 1712. 
Scriptures providing details for dividing the spoils from battle (Num 31:25-30; 1 Sam 30:24-25; The Temple Scroll from Qumran, 11QT [11Q19] 58.11-15). These texts also mention the priests, Levites, congregation, and the king among those who should receive a share of the booty. By focusing on the widows, orphans, elders, and the tortured, the author provides a link to those who had already been victims in the narrative.

Pritchett cites evidence from Diodorus (16.86.6) and Polyaenus (1.43.2; 7.43 ) on the ह่ $\pi \iota v$ ixı ("victory celebrations") mentioned in $8: 33 .{ }^{35}$ These celebrations also entailed sacrifices. Doran, however, rightly argues that the present order of 2 Maccabees, the term $\dot{\varepsilon} \pi \imath v_{i}$ x $1 \alpha$ could not have included the meaning of sacrifices, since the Temple had not yet been restored. ${ }^{36}$ Therefore, the broader meaning of victory celebrations should be maintained.

The theme of appropriate retribution is articulated in 8:33-36. Those who had burnt the holy gates were set on fire $(8: 33)$ and Nikanor, who has vainly planned to destroy the Jews is made low (8:34-36). The irony is communicated through the fact that Nikanor, who aimed at enslaving the Jews, is now acting like a slave, removing his splendid raiment ( $\tau \dot{\eta} \nu \delta_{0} \xi \ldots \dot{\eta} \nu \nu \dot{a} \pi \circ \theta \varepsilon \dot{\varepsilon} \mu \varepsilon \nu 0 \varsigma$

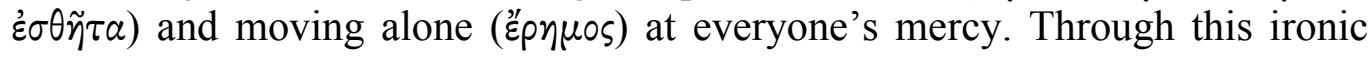
turn of events the author demonstrates that the God of the Jews is still in control.

\section{$3 \quad$ Proposition and argumentation}

At the offset of this pericope, it is clear that a dramatic shift occurs within the narrative flow of 2 Maccabees. This shift is visible through contrast in both theme and tone. The text emphasises this sudden change and utilises it in order to present a very specific proposition: the fate of the Jews is intimately connected to the scale of God's wrath and mercy. When his wrath drastically turns to mercy, the fate of the Jews drastically turns to reveal them as a divinely protected people. Tolerance of evil has turned to heavenly decreed vengeance.

The only proof for the abovementioned proposition would be to provide visible results that, now that God's wrath had turned to mercy, the Jews are actually finding significant and supernatural favour. Therefore this pericope introduces a new narrative part which will eventually build into the ultimate success of the Jews and the purification and reinstitution of the Jerusalem Temple. A key facet to evidencing such supernatural involvement is the character and actions of the hero Judas Maccabaeus. He becomes the embodiment of heavenly vengeance throughout the rest of the narrative.

35 Kendrick W. Pritchett, The Greek State at War, vol. 3 (Berkeley: University of California Press, 1971-1991), 186-189.

36 Doran, 2 Maccabees, 180. 


\section{PRAGMATIC ANALYSIS}

\section{Communicative strategy}

Such a strategic placing of the hero requires the establishment of unquestionable trust from the reader. If Judas and his followers are proof that God's mercy brings supernatural favour to the Jews, their actions should be seen as directly driven by God. The communicative strategy applied is thus one of legitimisation and vindication.

The pericope is introduced by Judas' recruitment of those who are steadfast in Judaism. The hope that was created through the breakaway of a new faction under Judas in 5:27 is now rewarded. Interestingly, the recruitment is also aimed at the reader. As the force of Judas grows in number and success, the reader is increasingly tempted to join the group of heroes. This happens by means of association and dissociation. The heroes have desirable traits and rewards and the villains have despicable traits and receive punishments. Logically, the reader would want to be a part of the group that is winning. The juxtaposition of, and the clear distinction between Judaism and Hellenism force the reader to make a drastic decision. There is no middle ground, only two extreme opposites. Since a choice for the villains is impossible, the reader has to vote for the heroes and everything they stand for. This becomes an ideal vehicle for propaganda through the actions and words of the heroes. The drive towards indisputable loyalty is further encouraged through singling out two lone-representatives of each party. Instead of groups of men, the stage is cleared for two individuals namely Judas and Nikanor.

Once the choice is made in support of the heroes, any potential doubt in this group is erased by means of a contract of trust. As mentioned above the text constructs a contract, not between the author and the reader, but between the characters and the reader. This happens by means of a process of justification. The heroes are proven to be (i) extremely pious and (ii) legitimised through an alliance with heaven. This delicate mixture implies that their choices and actions are sanctioned by the God of the Jews himself and are therefore pure and righteous.

Firstly, the text ensures the authority of the heroes, through proving their unequaled devotion and piety. The sudden success of the Jewish force is based solely on the change of status in the relationship between the Jews and their God. The author makes clear that the wrath of the Lord had turned to mercy (8:5). This is a clear prerequisite for conquering the enemy. In wrath the Jews suffer; in mercy they prosper. The presence of such a strategy, in turn, explains the explicit reference to the religious activities of Judas and his followers. They:

- pray to, and beseech God $(8: 2,14)$, 
- glorify God's name (8:15),

- give sermons (8:18),

- quote scriptures $(8: 19,20,23)$,

- give the slogan "God's help" (8:23),

- celebrate the Sabbath meticulously (8:26-28),

- and sing praises to the Lord $(8: 27)$.

Their piety and correct practice of essential elements are linked to that of the martyrs in 2 Macc 6-7. The text portrays these as the basis for the unusual success on the battlefield, since the description of Judas' victories comes directly after the description of the martyrs' obedience and Judas' prayer. The author further explicates the role of the heroes' piety through stating in 8:6 that the wrath of the Lord had turned to mercy. This is exactly what the youngest brother proclaimed in 7:33 and 7:38 as he himself outlined the relation between his martyrdom and the mercy of God that will follow. This heightened sense of authority of the heroes is strengthened by the linkage to the martyrs, a purification of the protagonist force, and their noble behavior.

Secondly, the text legitimises the heroes. This happens through association with the God of the Jews. He provides godlike success and he himself becomes an active ally to these righteous individuals. Such a legitimisation happens on various levels:

- The text focuses on the miraculous/impossible. A prominent theme is the few conquering the many. A mere 6000 Jews were divided into four groups of 1500 each (8:22). One of these groups slaughtered more than 9000 of Nikanor's men, wounded others, and forced the rest to flee (8:24). They also destroyed over twenty thousand of Timothy and Bachides' followers. The author further stresses this theme by dedicating 8:19-21 to the description of examples from the Jewish ancestry where the few had victory over the many. These victories are a symbol of God's providence and prove the fact that he himself is fighting against the enemies of his people $(8: 18)$.

- The text conditions the reader towards the correct view of Judas and his

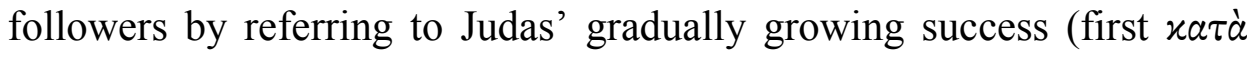

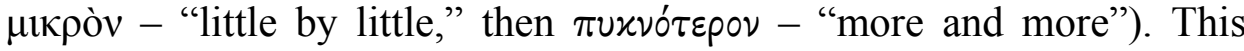
growth in success represents the growth in legitimacy of these heroes since such success clearly fuelled by heaven, the heroes are seen to be functioning under godly decree.

- As mentioned above, phrases like "God's Help" ( $\theta \varepsilon \circ$ ṽ $\beta o \eta \theta \varepsilon i ́ \alpha \varsigma)$ in 8:23 and terms such as "ally" ( $\sigma \dot{u} \mu \mu a \chi \circ)$ in 8:24 finalises the legimisation process through proving that the God of the Jews is, not only supporting, but actually driving and aiding the actions of the heroes. In addition, 
432 Coetzer, "Heroes and Villains," OTE 29/3 (2016): 419-433

God's involvement is substantiated through the presence of appropriate retribution, which can only be conceptualised as God's direct dealing with Nikanor and those who had burnt the holy gates.

\section{E CONCLUSION}

Consequently, the heroes and villains in 2 Macc 8 aid the reader in adopting specific ideas. The two groups are contrasted through distinctive character traits and actions of extreme opposites. The reader is further encouraged through the solo juxtaposition of the main hero and villain individually. Furthermore, the text ensures the clear communication of a proposition that demonstrates the contrasted implications of God's wrath and mercy. This proposition, in turn implies divine success in all the endeavours of the Jews. Consequently, the text lays out a series of events that prove a supernatural involvement. The instruments chosen for the application of divine fortune are the heroes of the text. In order to establish a contract of trust between the implicit reader and these heroes, Judas and his followers are portrayed as blameless and fully legitimised. In this manner the pericope is shown to be vital in establishing the reader's loyalty towards the heroes throughout the rest of the narrative. The heroes become the embodiment of God's vengeance and proof of his alliance with the Jews - a key part in the narrative plan to connect God's mercy with the good fortune of the Jewish people.

\section{BIBLIOGRAPHY}

Bar-Kochva, Bezalel. Judas Maccabaeus: The Jewish Struggle against the Seleucids. Cambridge: Cambridge University Press, 1989.

Bickerman, Elias J. The God of the Maccabees: Studies in the Meaning and Origin of the Maccabean Revolt. Leiden: Brill, 1979.

Coetzer, Eugene and Pierre J. Jordaan. "Investigating the Communicative Strategy in 2 Maccabees 3: Six Scenes which Influence the Reader throughout the Narrative.” HTS Teologiese Studies/Theological Studies 72 (2016): doi: 10.4102/hts.v72i3.3047.

Doran, Robert. 2 Maccabees: A Critical Commentary. Minneapolis: Fortress Press, 2012.

Gafni, Isaiah M. "Josephus and I Maccabees." Pages 116-131 in Josephus, the Bible, and History. Edited by Louis H. Feldman and Gåohei Hata. Leiden: Brill, 1989.

Goldstein, Jonathan A. II Maccabees: A New Translation with Introduction and Commentary. Garden City, N.Y.: Doubleday, 1983.

Jordaan, Pierre J. "The Temple in 2 Maccabees - Dynamics and Episodes." Journal for Semitics 24 (2015): 352-365.

Liddell, Henry G. and Scott, Robert, compilers. A Greek English Lexicon. Rev. enl. ed. by Henry S. Jones and Roderick McKenzie, 9th ed. Oxford: Clarendon Press, 1992.

Mørkholm, O. Antiochus IV of Syria. Classica et mediaevalia, dissertatioenes 8. Copenhagen: Gyldendal, 1966. 
Pritchett, Kendrick W. The Greek State at War. 5 vols. Berkeley: University of California Press, 1971-1991.

. Essays in Greek History. Amsterdam: Gieben, 1994.

Scholl, Reinhold. Corpus der ptolemäischen Sklaventexte. Stuttgart: Steiner, 1990.

Schwartz, Daniel R. 2 Maccabees. Berlin: Walter de Gruyter, 2008.

Van Henten, Jan-Willem. The Maccabean Martyrs as Saviours of the Jewish People: A Study of 2 and 4 Maccabees. Leiden: Brill, 1997.

\section{Classical literature (including Josephus)}

Apian, Bella Civilian 2.76.

Diodorus Siculus, 16.86.6.

Josephus, Antiquities 12.285.

Livy, 42.6.7.

Polyaenus, $1.43 .2 ; 7.43$.

Polybius, $1.81 .11 ; 3.53 .6 ; 8.26 .8 ; 21.42 .19$.

Xenophon, Anabasis 1.8.17; 6.5.26.

Cyropaedia 3.3.58.

Hiero 10.5 .

\section{Dead Sea Scrolls}

The Temple Scroll from Qumran, 11QT [11Q19] 58.11-15).

Dr. Eugene Coetzer, Post-Doctoral Fellow, Department Ancient Languages, Northwest University, Potchefstroom Campus. Private bag X6001, Potchefstroom, 2520.Email: 111coetzer@gmail.com. 